\title{
Importance Performance Analysis of Corporate Governance, Technology Monitoring and Credit Monitoring in Influencing Non-Performing Loans
}

\author{
Maswar Purnama*, Suhadak, Sri Mangesti Rahayu, Cacik Rut Damayanti \\ Faculty of Administrative Science \\ Universitas Brawijaya \\ Malang, Indonesia \\ *maswar@student.ub.ac.id
}

\begin{abstract}
This research is quantitative research that aims to examine the drivers of Non- Performing Loan Such as Technology Monitoring, Corporate Governance and Credit Monitoring variables. This research using primary data from questionnaires with Head of Micro Branch Office of Bank Mandiri in Central Java Region being a sample in this study. Judgment Sampling technique and IPA data analysis are used in this research. Research results show that Corporate Governance are located in quadrant 2 which indicates corporate governance as the variable that best reflects NPL. while the responsibility indicator is the indicator that best reflects the corporate governance variable, Credit Monitoring are located in quadrant 1 which indicates that Credit Monitoring need improvement in performance and Technology Monitoring located in quadrant 3 which indicates that Technology Monitoring is not very important in influencing the NPL rate. This research originality lies on using of Technology Monitoring variable that is separate from Credit Monitoring.
\end{abstract} $N P L$

Keywords-business administration, corporate governance,

\section{INTRODUCTION}

Bank Mandiri, as one of the largest banks in Indonesia, places the micro credit sector as one of its main products in getting customers. As a debtor, Bank Mandiri's credit problems cannot be separated from the uncontrolled NPL ratio. this NPL ratio affects the income of the Bank Mandiri. In addition, regulations from the Indonesia Financial Services Authority (OJK) require Bank Mandiri to reduce the NPL rate below 5\%.

According to the theory of financial intermediating monitoring, Diamond [1] states that the method used by banks can affect the level of credit by creditors. In addition, governance that is carried out by a bank can influence managerial actions which will also affect the level of credit monitoring. Tarchouna in his research also states that corporate governance has an impact on the risk of credit [2]. This research occurs by the same results from the research of Saada [3] and Ahmad et al [4]. That research becomes a theoretical basis for the application of corporate governance as one of the factors affecting a bank's NPL.

Piatti and Cincinelli [5] state that the credit supervision system has an important role in efforts to curb the rate of NPLs. The results of this study are supported by the results of similar studies from Boudriga et al [6] and Umar and Sun [7]. This research provides a theoretical basis for credit monitoring as an influencing factor for NPLs. Technology monitoring in this study which is apart from credit monitoring is a novelty in this study. This is based on the idea that technology is present as a factor that facilitates the monitoring process itself.

From the explanation above, 3 factors that influence NPL can be taken, namely corporate governance, credit monitoring and technology monitoring. Those factors will determine the level of importance and performance in determining which factors need to be prioritized in reducing the rate of NPLs. This research contributes to world banking, especially regarding credit and developing previous study from Purnama et al. [8].

\section{METHODS}

This study uses a quantitative approach, namely the approach used to examine a population or a particular sample, where the research data is quantitative (numeric), the data analysis uses statistical methods. The research instrument was a questionnaire. The data was collected by distributing questionnaires to several selected Bank Mandiri branches as samples. This research focuses on the area of Bank Mandiri Branch Offices in the Central Java Region. Where in this area is a densely populated area so that it has a large possibility of credit customers.

The unit of analysis in this study is an organization, namely the Bank Mandiri branch office in Central Java. This is based on the premise that the research variables which include corporate governance, credit monitoring and technology monitoring are characteristics of the organization (Bank Mandiri). The population of this study is all Bank Mandiri Micro Branch Offices (KCM) in Central Java, amounting to $\mathrm{N}$ 
$=145$ KCM. Judgment Sampling technique used in this study, this technique selecting sample based on certain criteria. Seven areas of Bank Mandiri in the Central Java Region become a population on this research. The criteria used are micro branch offices (KCM) in 3 areas with the largest loan portfolios in Central Java. As the 3 areas with the largest loan portfolio, the Semarang, Solo and Kudus areas were sampled in this study with a total of $78 \mathrm{KCM}$. The collected data will be analyzed using IPA analysis. IPA analysis is used because this method can classify which factors need to be prioritized in improving performance based on the importance of each factor.

\section{RESULtS}

The results of the questionnaire from $78 \mathrm{KCM}$ samples will then be processed based on the importance value and performance of each variable and indicator. Importance value and performance data are presented in the following table 1:

TABLE I. TABLE IMPORTANCE AND PERFORMANCE PER INDICATOR

\begin{tabular}{|c|c|c|c|}
\hline Variable & Indicators & $\begin{array}{c}\text { Importance } \\
(\%)\end{array}$ & $\begin{array}{c}\text { Performance } \\
(\%)\end{array}$ \\
\hline \multirow{5}{*}{$\begin{array}{l}\text { Corporate } \\
\text { Governance } \\
\text { (CG) }\end{array}$} & Transparency (CG1) & 20.59 & 46.18 \\
\hline & Accountability (CG2) & 20.59 & 40.73 \\
\hline & Responsibility (CG3) & 63.07 & 84.36 \\
\hline & Independency (CG4) & 51.63 & 32.55 \\
\hline & Fairness (CG5) & 23.85 & 44.18 \\
\hline \multirow{3}{*}{$\begin{array}{l}\text { Credit } \\
\text { Monitoring } \\
(\mathrm{CM})\end{array}$} & $\begin{array}{l}\text { Client } \\
\text { (CM1) }\end{array}$ & 52.60 & 59.04 \\
\hline & $\begin{array}{l}\text { Credit } \\
\text { (CM2) }\end{array}$ & 70.00 & 63.88 \\
\hline & $\begin{array}{l}\text { Porto folios } \\
\text { Monitoring (CM3) }\end{array}$ & 30.00 & 27.08 \\
\hline \multirow{3}{*}{$\begin{array}{l}\text { Technology } \\
\text { Monitoring } \\
\text { (TM) }\end{array}$} & Organization (TM1) & 67.88 & 29.12 \\
\hline & Purpose (TM2) & 28.15 & 68.98 \\
\hline & $\begin{array}{l}\text { Implementation } \\
\text { (TM3) }\end{array}$ & 51.99 & 51.90 \\
\hline
\end{tabular}

Apart from data on the importance and performance values of each indicator, there are also importance and performance values for each variable in the following table 2 :

TABLE II. TABLE IMPORTANCE AND PERFORMANCE PER VARIABLE

\begin{tabular}{|l|l|l|}
\hline \multicolumn{1}{|c|}{ Variable } & \multicolumn{1}{|c|}{ Importance (\%) } & Performance (\%) \\
\hline $\begin{array}{l}\text { Corporate } \\
\text { Governance (CG) }\end{array}$ & 70.38 & 72.46 \\
\hline $\begin{array}{l}\text { Credit Monitoring } \\
(\mathrm{CM})\end{array}$ & 52.78 & 43.41 \\
\hline $\begin{array}{l}\text { Technology } \\
\text { Monitoring (TM) }\end{array}$ & 30.40 & 34.13 \\
\hline
\end{tabular}

The data will be compared to the level of importance and perceived performance of the respondents in a Cartesian diagram. The results of the IPA analysis are presented in the following figure 1 :

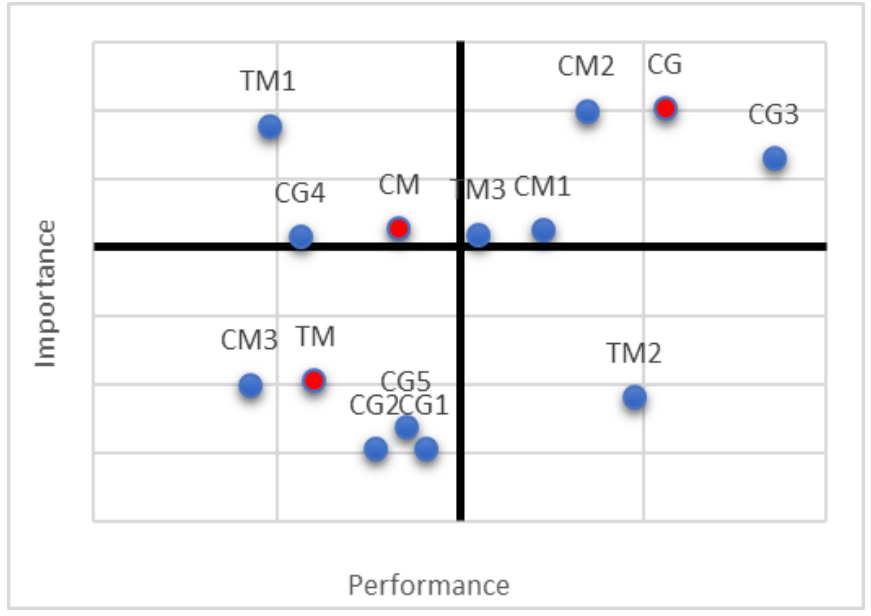

Fig. 1. IPA cartesius chart

Cartesian chart shows that in quadrant 1 there are indicators TM1, CG4 and Variable CM. Indicators and variables located in quadrant 1 are factors that are considered important by respondents but the performance of these factors in the real world is still considered insufficient. Factors located in this quadrant need to be prioritized in improving performance in order to balance the importance of these factors.

In quadrant 2 there are indicators TM3, CM1, CM2, CG3 and Variable CG. Indicators and variables in quadrant 2 are indicators that are considered important by respondents and their performance is considered satisfactory. The factors in this quadrant are factors that are expected to maintain the level of performance.

In quadrant 3 there are indicators CM3, CG2, CG5, CG1 and Variable TM. Indicators and variables in this quadrant are factors that respondent consider insignificant and have low performance. The factor in this quadrant is a low priority factor in efforts to improve performance.

In quadrant 4 there is only TM2 indicator which is the only factor in that quadrant. Respondents considered these indicators as a less important factor but have a high level of performance. Factors in this quadrant can be sacrificed in an effort to improve the performance of other factors that are considered more important.

\section{DiscUSSION}

The results of the analysis show that there are 2 indicators and 1 variable that need special attention in improving performance. The organization indicator (TM1) is considered by respondents to have a high level of importance, namely $67.88 \%$. the high importance level has not been matched by the performance level which is only $29.12 \%$. The independence indicator (CG4) is considered by respondents to have a high level of importance, namely $51.63 \%$. the high importance level has not been matched by the performance level which is only $32.55 \%$. and the variable credit monitoring $(\mathrm{CM})$ is considered by respondents to have a high importance, namely $52.78 \%$. the high importance level has not been matched by the performance level which is only $43.41 \%$. 
These three factors are related to the monitoring technology organization, the level of company independence and the level of goodness of the monitoring credit from the Bank. These factors have an important effect, but in reality, they are still not satisfactory in their implementation. These findings can serve as an evaluation of Bank Mandiri in the process of strategy formulation and implementation of the factors in quadrant 1. These efforts are expected to be able to improve the performance of the TM1, CG4 and CM variable indicators.

The results of the analysis show that there are 4 indicators and 1 variable whose performance level needs to be maintained. Respondents considered Indicator implementation (TM3) to have a high level of importance, namely $51.99 \%$. the high importance level has been balanced with the performance level which is only $51.90 \%$. The responsibility indicator (CG3) is considered by respondents to have a high level of importance, namely $63.07 \%$. the high importance level has been balanced with the performance level which is only $84.36 \%$. The client monitoring indicator (CM1) is considered by respondents to have a high level of importance, namely $52.60 \%$. the high importance level has been balanced with the performance level of only $59.04 \%$. Respondents considered the credit assessment indicator (CM2) to have a high importance level of $70.00 \%$. the high importance level has been balanced with the performance level of only $63.88 \%$. and the corporate governance $(\mathrm{CG})$ variable is considered by respondents to have a high level of importance, namely $70.38 \%$. the high importance level has been balanced with the performance level which is only $72.46 \%$.

The five factors are related to the implementation of monitoring technology, the level of corporate responsibility, client supervision, credit assessment and the level of good governance of the Bank. These factors have an important influence and have a satisfactory performance in implementation. These findings can serve as a reference for Bank Mandiri in the process of maintaining the quality of the performance of the factors in quadrant 2. These efforts are expected to be able to maintain the performance of the TM3, CM1, CM2, CG3 and CG variable indicators.

The results of the analysis show that there are 4 indicators and 1 variable that can be prioritized. The respondents considered the porto folios monitoring indicator (CM3) to have a low level of importance, namely $30.00 \%$. The low importance level is followed by a performance level of only $27.08 \%$. The transparency indicator (CG1) was considered by respondents to have a low level of importance, namely $20.59 \%$. The low importance level is followed by the performance level which is only $46.18 \%$. The accountability indicator (CG2) is considered by respondents to have a low level of importance, namely $20.59 \%$. The low importance level is followed by a performance level of only $40.73 \%$. The fairness indicator (CG5) is considered by respondents to have a low level of importance, namely $23.85 \%$. The low importance level is followed by the performance level which is only $44.18 \%$. and the technology monitoring (TM) variable was considered by respondents to have a low level of importance, namely $30.40 \%$. The low importance level is followed by a performance level of only $34.13 \%$.
The five factors relate to portfolio supervision, the level of company transparency, the level of company accountability, the level of company fairness and the level of technology supervision of the Bank. These factors are less important factors and have low performance in their implementation. These findings can serve as a reference for Bank Mandiri in prioritizing improving the performance of factors other than those in quadrant 3. These efforts are expected to be able to improve the performance of other prioritized factors.

The analysis results also show that there is 1 indicator that performance can be sacrificed in order to improve the performance of other more priority factors. Purpose indicator (TM2) is considered to have a low level of importance, which is $28.15 \%$ but has a high performance of $68.98 \%$. these factors are related to meeting the objectives of the monitoring technology. These indicators are considered to have high performance despite of their low importance. The performance of these indicators can be sacrificed by Bank Mandiri in an effort to improve the performance of other, more priority factors.

\section{CONCLUSION}

Based on the research results, it can be seen that Corporate Governance are located in quadrant 2 which indicates corporate governance as the variable that best reflects the NPL. while the responsibility indicator is the indicator that best reflects the corporate governance variable, Credit Monitoring is located in quadrant 1 which indicates that Credit Monitoring needs improvement in performance and Technology Monitoring is located in quadrant 3 which indicates that Technology Monitoring is not very important in influencing the NPL rate.

Based on these conclusions, Bank Mandiri could be more focused on improving credit monitoring and maintaining the level of corporate governance performance in an effort to reduce the rate of NPLs. Bank Mandiri can also prioritize maintaining the level of performance from responsibility and credit assessment as the factors that best describe the corporate governance and credit monitoring variables.

The results of this study have implications in the form of theory development on corporate governance variables, credit monitoring and monitoring technology primarily related to the application in the banking world. In addition, this research also has implications for the banking sector, especially the credit sector in modeling non-performing loans and the factors that influence it.

\section{REFERENCES}

[1] D.W. Diamond, "Financial Intermediation as Delegated Monitoring: A Simple Example," FRB Richmond Econ. Q., vol. 82, no. 3, pp. 51-66, 1996.

[2] A. Tarchouna, B. Jarraya, and A. Bouri, "How to Explain NonPerforming Loans by Many Corporate Governance Variables Simultaneously? A Corporate Governance Index Is Built to US Commercial Banks,” Res. Int. Bus. Financ., vol. 42, pp. 645-657, 2017.

[3] M. Ben Saada, "The Impact of Control Quality on the Non-Performing Loans of Tunisian Listed Banks,” Manag. Audit. J., 2017. 
[4] M.I. Ahmad, W. Guohui, M. Hassan, M.A. Naseem, and R.U. Rehman, "NPL and Corporate Governance: A Case of Banking Sector of Pakistan," Account. Financ. Res., vol. 5, no. 2, pp. 32-41, 2016.

[5] D. Piatti and P. Cincinelli, "Does the Threshold Matter? The Impact of the Monitoring Activity on Non-Performing Loans: Evidence from the Italian Banking System,” Manag. Financ., 2019.
[6] A. Boudriga, N.B. Taktak, and S. Jellouli, "Banking Supervision and Nonperforming Loans: A Cross-country Analysis," J. Financ. Econ. policy, 2009.

[7] M. Umar and G. Sun, "Determinants of Non-Performing Loans in Chinese Banks,” J. Asia Bus. Stud., 2018.

[8] M. Purnama, S. Mangesti, and C.R. Damayanti, "The Effect of Modification of Technology Monitoring on Relationship Between Corporate Governance, Credit Monitoring, and Npl," 2020. 